\title{
Allometric growth of non-carcass components in crossed lambs
}

\section{Crescimento alométrico dos não componentes da carcaça de cordeiros cruzados}

\author{
Iraides Ferreira Furusho Garcia ${ }^{\mathrm{I}^{*}}$ Tharcilla Isabella Rodrigues Costa Alvarenga ${ }^{\mathrm{I}}$ \\ Juan Ramon Olalquiaga Perez ${ }^{\mathrm{I}}$ Amelia Katiane de AlmeidaII Sarita Bonagurio Gallo ${ }^{\mathrm{III}}$

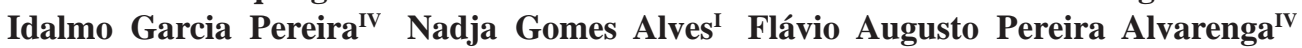

\section{ABSTRACT}

Males and females, including purebred Santa Inês lamb (SI) and crosses between Santa Inês dams and Texel (TxSI), Ile de France (IFxSI) and Bergamasca (BxSI) sires were feedlot finished and slaughtered at 15, 25, 35 and $45 \mathrm{~kg}$ live weight. After slaughter, the following non- carcass components were weighed and calculated the allometric growth. Lungs of BxSI males grew faster than those of SI and TxSI. Trachea/esophagus in SI and TxSI males grew slower than IFxSI and BxSI. Kidneys BxSI males grew faster than TXSI and IFxSI. Livers of female TxSI lamb grew more rapidly than those of females in the other genetic groups. In both males and females, the rumen/reticulum grew faster in the TxSI group than SI and BxSI groups.

Key words: allometry, growth, crossbreed, body development, sheep.

\section{RESUMO}

Machos e fêmeas, Santa Inês puros (SI) e cruzados de matrizes Santa Inês com reprodutores das raças Texel (TxSI), Ile de France (IFxSI) e Bergamácia (BxSI), terminados em confinamento e abatidos aos 15, 25, 35 e 45kg de peso vivo. Após o abate, foram tomados os pesos das vísceras e analisado o crescimento alométrico. O pulmão dos machos BxSI cresceu em taxas mais elevadas que SI e TxSI. A tráqueia/esôfago dos machos SI e TxSI cresceu mais lentamente que dos IFxSI e BxSI. Os rins dos machos BxSI cresceram mais rápido comparado aos dos TxSI e IFxSI. O fígado das fêmeas TxSI cresceu em taxas mais elevadas quando comparadas às fêmeas dos outros grupos genéticos. Os machos e fêmeas do grupo TxSI apresentaram taxas de crescimento maiores para rúmen/retículo, respectivamente, comparado aos grupos SI e BxSI.

Palavras-chave: alometria, crescimento, desenvolvimento corporal, cruzamento, ovinos.

\section{INTRODUCTION}

The choose of crossing to be adopted for sheep production activity is defined with what the farmer would like to explore, and should direct the selection to better maternal ability, prolificity, weaning rates, feed conversion, fast growing of the lambs and improved carcass quality and meat produced. The rearing of sheep for meat production is growing in Brazil, but slaughtering these animals produces, in addition to the carcass, considerable quantities of other body components. These components are also usable and are known as the non-carcass components or "the fifth quarter" (ROSA et al., 2002). Non-carcass body components are important parts that should be studied more carefully, especially because they influence the yield of the edible parts of the animal that are economically valuable and because some components are directly related to basal metabolism. According to CARVALHO et al. (2005), the relative weight of non-carcass components ranges from 40 to $60 \%$ of live weight. This proportion is influenced by genetics, age, live weight, sex, type of birth and diet.

Growth involves changes in both body size and structure over an animal's productive lifespan (HAMMOND, 1966). This process includes the tissues of organs and other body parts, including muscles, bones and fat, which undergo distinct growth periods depending on the growth phase and

\footnotetext{
'Departamento de Zootecnia, Universidade Federal de Lavras (UFLA), Campus Universitário, CP 3037, 37200-000, Lavras, MG, Brasil. E-mail: iraides.ufla@gmail.com.*Autor para correspondência.

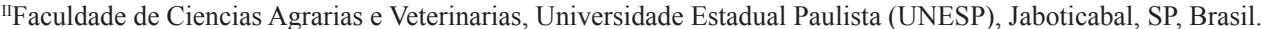

IIIFaculdade de Zootecnia e Engenharia de Alimentos, Universidade de São Paulo (USP), Pirassununga, SP, Brasil.

${ }^{\text {IV }}$ Departamento de Zootecnia, Universidade Federal de Minas Gerais (UFMG), Belo Horizonte, MG, Brasil. 
physiological maturity of the animal (BERG \& BUTTERFIELD, 1976). The growth of body parts can be studied allometrically to explain the quantitative differences between each animal category (SANTOS et al., 2001), and this development can be measured using formulas and nonlinear models such as the equation from HUXLEY (1932).

SOUZA JÚNIOR et al. (2009) noted that research has shown that body component development in lamb may be precocious, delayed or, in some cases, even isogonic, depending on the genetic group, sex, feeding methods, slaughter weight and the type of cut, body component or tissue analyzed. According to KIRTON et al. (1995), the breed and sex are among the major sources of variation affecting body composition in animals raised for meat production. The breed or crossing used for meat production may influence the weight of non-carcass components and therefore the yield (PINHEIRO et al., 2008). The growth rate and final weight of the lamb achieved at slaughter are aspects related with the genetic or crossbreed that was assigned to it, and the rates hot and cold carcass yield and non carcass components are inversely correlated. FURUSHO-GARCIA (2003) found proportional differences in the noncarcass components of genetically distinct groups that were slaughtered at the same age.

Therefore, this research aims to asses to analyze the growth of non-carcass components in male and female purebred Santa Inês lamb and crosses between Santa Inês ewes with Texel, Ile de France and Bergamasca sires that were between 15 and $45 \mathrm{~kg}$ live weight and were feedlot finished.

\section{MATERIALS AND METHODS}

The experiment was conducted in the sheep husbandry facility of the Animal Science Department at Federal University of Lavras. It was used 103 lambs, including both males and females, from crosses between Santa Inês dams and Santa Inês (SI), Texel (TxSI), Ile de France (IFxSI) and Bergamasca (BxSI) sires, which were weaned at an average weight of $10 \mathrm{~kg}$. The following numbers of animals were analyzed (males and females): 13 and 14 SI; 13 and 14 TxSI; 10 and $8 \mathrm{FS}$; and 12 and $19 \mathrm{BS}$. The average age at the start of the trial period was of 78.89 days $( \pm 7,07)$. A total of 24, 28, 26 and 25 animals were slaughtered at $15,25,35$ and $45 \mathrm{~kg}$, respectively.

At an average live weight of $14 \mathrm{~kg}( \pm 1.35)$, the lambs were individually confined in pens measuring $1.3 \mathrm{~m}^{2}$ of floor space with individual food and water troughs. Animals were weighed weekly until slaughter and were fed ad libitum throughout the experiment with a diet balanced according to ARC (1980) recommendations for $300 \mathrm{~g} \mathrm{day}^{-1}$ weight gain, which was composed of $80 \%$ pellets and $20 \%$ cut Bermudagrass (Cynodon dactylon).

Animals of both genders from every genetic group were randomly divided into pre-established slaughter weight categories $(15,25,35$ and $45 \mathrm{~kg})$. Lamb slaughtered at $15 \mathrm{~kg}$ were not individually confined. Animals were deprived of solids for 16 hours prior to slaughter. During slaughter, blood and skin were collected and weighed, and filled viscera were removed. Visceral contents were weighed and subtracted from the slaughter weight after fasting to calculate the empty body weight. The following body components were also weighed: head, skin, feet/ankles, tail, testicles, mammary gland, trachea/ esophagus, lung, heart, liver, bladder, diaphragm, spleen, pancreas, kidneys, rumen/reticulum, omasum, abomasum, small intestine and large intestine. Pelvic, kidney and omental fat and the mesentery + fat were also measured. The relative growth of the non-carcass body components normalized to the growth of the empty body was analyzed using the exponential equation $\mathrm{Yi}=\mathrm{a} \mathrm{Xi}^{\mathrm{b}} \varepsilon \mathrm{i}$, logarithmically transformed to a linear model (HUXLEY, 1932):

$\ln Y_{i}=\ln a+b \ln X+\ln \varepsilon_{i}$, wherein:

$\mathrm{Y}_{\mathrm{i}}=$ measures (non-carcacass components);

$\mathrm{X}=$ weight of the live animal;

$\mathrm{a}=$ the intercept of the linear regression logarithm about "Y" and "b";

$\mathrm{b}=$ coefficient of relative growth and allometry;

$\varepsilon_{\mathrm{i}}=$ multiplicative error;

$\mathrm{Ln}=$ Napierian logarithm.

Data were analyzed using the REG procedure in the Statistical Analysis System (SAS, 1999) program. A t-test was employed to test the hypothesis $\mathrm{H}_{0}: \beta=1$. Growth was considered isogonic when $b=1$, indicating similar growth rates for $\mathrm{X}$ and $\mathrm{Y}$ during the analyzed growth interval. Growth was considered to be heterogonic for $b \neq 1$ and was positive for $b>1$ and negative for $b<1$. The allometric coefficients were tested using the F-test to compare the genetic groups using a binary variable (GRAYBILL, 1976; REGAZZI \& LEITE, 1992; REGAZZI, 1993) to identify the regression coefficients for each genetic group.

\section{RESULTS AND DISCUSSION}

Male lamb from all of the genetic groups and females from the Ile de France $\mathrm{x}$ Santa Inês and Bergamasca x Santa Inês crosses presented allometric 
coefficients of less than 1 for the feet/ankles (Table 1), corresponding to negative heterogonic growth. Thus, for these animals, this component grows faster than the animal's empty body. Purebred Santa Inês and Texel x Santa Inês females exhibited coefficients equal to one (Table 1), representing isogonic growth, indicating that the feet/ankles in these lambs grew at a similar rate to the empty body.

Except to Bergamasca x Santa Inês females, the allometric coefficients for the heads were less than one (Table 2), indicating negative heterogonic growth, as the head grew faster than the empty body. Bergamasca x Santa Inês females showed isogonic growth as their allometric coefficient was one (Table 2), thus showing that the heads of these lamb grow at the same rate as the empty body. Bergamasca breed is larger (OLIVEIRA et al., 2003) than the other breeds crossed in this study, which may have contributed to this result. Ile de France x Santa Inês males had an allometric coefficient for the head that was less than the purebred Santa Inês and the Bergamasca x Santa Inês lamb, i.e., their growth rate was lower.

All of the sheep, except for the Bergamasca $\mathrm{x}$ Santa Inês males, presented skin allometric coefficients less than one (Table 2). Therefore, the skin grew isogonically, indicating growth at the same rate as the empty body. Bergamasca x Santa Inês males exhibited a skin allometric coefficient greater than one (Table 1), indicative of positive heterogonic growth; i.e., their skin grew slower than the empty body. Because Bergamasca lambs are larger and these lambs were males, the growth of other components was likely prioritized during this growth phase, especially because this genetic group was covered with wool. The coefficients did not differ between groups, indicating that the growth rate of skin between 15 and $45 \mathrm{~kg}$ live weight is independent of the genetic background of the animals that were studied.

Table 1 - Allometric coefficients of internal organs from purebred and crossbreed Santa Inês male lambs.

\begin{tabular}{|c|c|c|c|c|}
\hline \multirow[t]{2}{*}{ Component } & \multicolumn{4}{|c|}{ - } \\
\hline & SS & TS & FS & BS \\
\hline Feet/ankles & $0.7781 * *$ & $0.6283 * *$ & $0.6715^{* *}$ & $0.7660^{* *}$ \\
\hline Head & $0.7619 * *$ & $0.662^{* *}$ & $0.6067 * *$ & $0.7689 * *$ \\
\hline Skin & $1.1407^{\mathrm{ns}}$ & $0.9809^{\mathrm{ns}}$ & $1.1769^{\mathrm{ns}}$ & $1.1722^{\mathrm{ns}}$ \\
\hline Tail & $1.2691^{\mathrm{ns}}$ & $1.2370^{\mathrm{ns}}$ & $1.1950^{\mathrm{ns}}$ & $1.1648^{\mathrm{ns}}$ \\
\hline Diaphragm & $0.9941^{\mathrm{ns}}$ & $1.0000^{\mathrm{ns}}$ & $1.0000^{\mathrm{ns}}$ & $0.4302^{\mathrm{ns}}$ \\
\hline Lung & $0.4906^{* *}$ & $0.4784 * *$ & $0.6786^{*}$ & $0.8132^{\mathrm{ns}}$ \\
\hline Trachea/esophagus & $0.7176^{*}$ & $0.7269^{*}$ & $1.3225^{\mathrm{ns}}$ & $1.0815^{\mathrm{ns}}$ \\
\hline Heart & $0.9899^{\text {ns }}$ & $1.0926^{\mathrm{ns}}$ & $0.8094^{\mathrm{ns}}$ & $1.0572^{\mathrm{ns}}$ \\
\hline Pancreas & $0.4722^{*}$ & $0.5249 * *$ & $0.6547 *$ & $0.5391 * *$ \\
\hline Spleen & $0.8646^{\mathrm{ns}}$ & $1.1199^{\mathrm{ns}}$ & $0.7492^{\mathrm{ns}}$ & $1.0576^{\mathrm{ns}}$ \\
\hline Kidneys & $0.7061^{\mathrm{ns}}$ & $0.6187^{* *}$ & $0.5659^{* *}$ & $1.0471^{\mathrm{ns}}$ \\
\hline Bladder & $0.4717^{*}$ & $0.6102^{\mathrm{ns}}$ & $0.8665^{\mathrm{ns}}$ & $1.3586^{\mathrm{ns}}$ \\
\hline Liver & $0.7385^{* *}$ & $0.8984 *$ & $0.7530^{\mathrm{ns}}$ & $0.7691 *$ \\
\hline Rumen/reticulum & $0.6802 * *$ & $0.8256^{* *}$ & $0.6684 * *$ & $0.5128 * *$ \\
\hline Omasum & $0.7881^{\mathrm{ns}}$ & $0.7894^{\mathrm{ns}}$ & $0.7115^{\mathrm{ns}}$ & $0.7143^{\mathrm{ns}}$ \\
\hline Abomasum & $0.6885^{*}$ & $0.6048^{*}$ & $0.8274^{\mathrm{ns}}$ & $0.6860 *$ \\
\hline Small intestine & $0.7858^{\mathrm{ns}}$ & $0.7156^{*}$ & $0.5247^{\mathrm{ns}}$ & $0.5840^{\mathrm{ns}}$ \\
\hline Large intestine & $0.4772 * *$ & $0.5624 * *$ & $0.5729^{*}$ & $0.5849 * *$ \\
\hline Omental fat & $0.3797^{\mathrm{ns}}$ & $0.3890^{\mathrm{ns}}$ & $1.0441^{\mathrm{ns}}$ & $0.6126^{\mathrm{ns}}$ \\
\hline Mesentery and fat & $2.0516^{*}$ & $1.6081^{* *}$ & $1.2561^{\mathrm{ns}}$ & $1.6446^{* *}$ \\
\hline Pelvic fat & $1.6093 * *$ & $1.9625^{* *}$ & $1.6498^{*}$ & $1.9927 * *$ \\
\hline Kidney fat & $2.0516^{*}$ & $2.3114 * *$ & $2.2698 * *$ & $2.7463 * *$ \\
\hline Testicles & $2.5319 * *$ & $2.3247 * *$ & $2.2581 * *$ & $2.4772 * *$ \\
\hline
\end{tabular}

$* *=\mathrm{P}<0.01, *=\mathrm{P}<0.05, \mathrm{~ns}=$ not significant. Purebred Santa Inês (SS). Santa Inês $\mathrm{x}$ Texel (TS). Santa Inês $\mathrm{x}$ Ile de France (FS). Santa Inês $\mathrm{x}$ Bergamasca (BS). 
Table 2 - Allometric coefficients of internal organs from purebred and crossbreed Santa Inês lamb females.

\begin{tabular}{|c|c|c|c|c|}
\hline \multirow[t]{2}{*}{ Component } & \multirow[b]{2}{*}{ SS } & \multicolumn{2}{|c|}{---Genetic Group- } & \multirow[b]{2}{*}{ BS } \\
\hline & & TS & $\mathrm{FS}$ & \\
\hline Feet/ankles & $0.6882^{\mathrm{ns}}$ & $0.6700^{\mathrm{ns}}$ & $0.5684 * *$ & $0.6179 * *$ \\
\hline Head & $0.6972 * *$ & $0.7022 * *$ & $0.6715^{* *}$ & $0.6507^{\mathrm{ns}}$ \\
\hline Skin & $0.9594^{\mathrm{ns}}$ & $0.9345^{\mathrm{ns}}$ & $0.8759^{\mathrm{ns}}$ & $1.0136^{*}$ \\
\hline Tail & $1.5238 * *$ & $1.2538^{\mathrm{ns}}$ & $1.4186^{* *}$ & $1.3303^{*}$ \\
\hline Diaphragm & $0.8328 *$ & $0.9088^{\mathrm{ns}}$ & $0.9381^{\mathrm{ns}}$ & $1.0022^{\mathrm{ns}}$ \\
\hline Lung & $0.4128 * *$ & $0.5434 * *$ & $0.4632 *$ & $0.4069 * *$ \\
\hline Trachea/esophagus & $0.6303^{\mathrm{ns}}$ & $1.2101^{\mathrm{ns}}$ & $0.7052^{\text {ns }}$ & $0.8075^{\mathrm{ns}}$ \\
\hline Heart & $0.7216^{\mathrm{ns}}$ & $0.7097^{\mathrm{ns}}$ & $0.6510^{*}$ & $0.8468 *$ \\
\hline Pancreas & $0.7237 *$ & $0.6079^{\mathrm{ns}}$ & $0.4616^{\mathrm{ns}}$ & $0.5282 * *$ \\
\hline Spleen & $1.1831^{\mathrm{ns}}$ & $0.9144^{\mathrm{ns}}$ & $0.8798 *$ & $0.8701^{\mathrm{ns}}$ \\
\hline Kidneys & $0.4903 * *$ & $0.5559 * *$ & $0.5340 * *$ & $0.4769 * *$ \\
\hline Bladder & $0.7931^{\mathrm{ns}}$ & $1.8428^{\mathrm{ns}}$ & $0.3473^{\mathrm{ns}}$ & $1.2949^{\mathrm{ns}}$ \\
\hline Liver & $0.5735^{* *}$ & $1.0273^{\mathrm{ns}}$ & $0.6563 * *$ & $0.5391 * *$ \\
\hline Rumen/reticulum & $0.3980 * *$ & $0.7076^{*}$ & $0.5251^{* *}$ & $0.5777 * *$ \\
\hline Omasum & $0.6633^{* *}$ & $0.8646^{\mathrm{ns}}$ & $0.7999^{\mathrm{ns}}$ & $0.6425 * *$ \\
\hline Abomasum & $0.6836^{*}$ & $0.6153 * *$ & $0.7830^{\mathrm{ns}}$ & $0.5991 * *$ \\
\hline Small intestine & $0.7472 * *$ & $0.7119 * *$ & $0.5701 * *$ & $0.5567 * *$ \\
\hline Large intestine & $0.4187 * *$ & $0.4795 * *$ & $0.4579 * *$ & $0.5243 * *$ \\
\hline Omental fat & $0.8879^{\mathrm{ns}}$ & $0.7563^{\mathrm{ns}}$ & $0.7575^{\mathrm{ns}}$ & $0.7955^{\mathrm{ns}}$ \\
\hline Mesentery and fat & $1.7841^{\mathrm{ns}}$ & $1.6381^{\mathrm{ns}}$ & $1.6484^{\mathrm{ns}}$ & $1.8172^{\mathrm{ns}}$ \\
\hline Pelvic fat & $2.0591 * *$ & $2.2390 * *$ & $1.2451^{\mathrm{ns}}$ & $1.9443 * *$ \\
\hline Kidney fat & $2.6156^{\mathrm{ns}}$ & $3.4010^{\mathrm{ns}}$ & $2.8076^{* *}$ & $2.6601^{\mathrm{ns}}$ \\
\hline Mammary Gland & $1.6571^{\mathrm{ns}}$ & $2.0012^{* *}$ & $1.2493^{\mathrm{ns}}$ & $1.3370^{\mathrm{ns}}$ \\
\hline
\end{tabular}

$* *=\mathrm{P}<0.01, *=\mathrm{P}<0.05, \mathrm{~ns}=$ not significant. Purebred Santa Inês (SS). Santa Inês x Texel (TS). Santa Inês x Ile de France (FS). Santa Inês $\mathrm{x}$ Bergamasca (BS).

Purebred Santa Inês, Ile de France $\mathrm{x}$ Santa Inês and Bergamasca $\mathrm{x}$ Santa females exhibited coefficients greater than one for the tail (Table 2), corresponding to positive heterogonic growth, indicating that the tail of these lambs grows slowerthan the empty body. Because the tails of all of the animals in the study were removed between the $2^{\text {nd }}$ and $3^{\text {rd }}$ coccygeal vertebrae and the bottom of the tail is an area with a large percentage of fat as well as the fact that females deposit larger proportions of fat, the slow growth of this region grows is likely due to the typically late development of adipose tissue. Other lamb presented allometric coefficients equal to one (Table 2), indicating that their tails grew at a similar rate to the empty body (isogonic growth). There were no differences detected between the allometric coefficients of the different genetic groups, indicating that the growth rate of the tail is not dependent on the genetic background of the animals examined in the present study.

In all of the genetic groups studied, the testicles developed slowly compared to the empty body, as their allometric coefficient was greater than one (Table 1), indicating positive heterogonic growth. The growth rate did not differ between genetic groups. It was observed negative heterogonic growth $(b<1)$ for the lungs; i.e., this organ grows more rapidly than the empty body, except for in Bergamasca x Santa Inês males (Table 1). Lungs of these animals grew at a similar rate to the empty body and exhibited a larger allometric coefficient compared to the purebred Santa Inês and Texel $\mathrm{x}$ Santa Inês males (F-test $=0.0175)$ in the weight range studied. Therefore, lungs of Bergamasca x Santa Inês males show a slower growth rate than those of purebred Santa Inês and Texel x Santa Inês males (F-test=0.0254).

Trachea/esophagus showed isogonic growth $(b=1)$, meaning that this component grew at a similar rate to the empty animal, except in the purebred Santa Inês and Texel x Santa Inês males, whose trachea/esophagus grew faster than the empty body $(\mathrm{P}<0.05)$. Lamb from the Ile de France $\mathrm{x}$ Santa Inês and Bergamasca $\mathrm{x}$ Santa Inês groups presented coefficients of less than one (negative heterogonic growth) for the heart, indicating that it grew faster than 
the empty body in the studied weight range. This organ showed isogonic growth in the other animals. Bladders of all lambs, except for those of purebred Santa Inês males, grew at a rate similar to the empty body.

All of the animals exhibited negative heterogonic growth for the liver $(\mathrm{P}<0.05)$; i.e., this organ grew faster than the empty body, except in Ile de France x Santa Inês males and Texel x Santa Inês females, who showed isogonic growth. When the coefficients were compared between genetic groups, Texel x Santa Inês females were observed to show a higher value than the other groups studied (F-test=0.0027).

With the exception of the Ile de France $\mathrm{x}$ Santa Inês females, all of the genetic groups, both males and females, exhibited allometric coefficients equal to 1 for the spleen; i.e., this organ showed isogonic growth, meaning that it grew at a rate similar to the empty body. There was no significant difference $(\mathrm{P}<0.05)$ between the genetic groups, indicating that the growth rates of the spleen were similar in all of the examined genetic groups.

The purebred Santa Inês and Bergamasca $x$ Santa Inês males showed isogonic growth $(b=1)$ for the kidneys; i.e., this body component grew at a rate similar to the empty body. However, in the other animals, the growth rate for the kidneys was faster than that of the empty body (Table 1). When the effects of the genetic groups were evaluated, it was found that Bergamasca x Santa Inês males showed growth rates that were different than the Texel x Santa Inês $(\mathrm{F}$-test $=0.0309)$ and Ile de France $x$ Santa Inês $(\mathrm{F}$-test $=0.0355)$, suggesting that the growth rate of this organ was different between genotypes.

All of the lambs, except for the purebred Santa Inês females, showed an allometric coefficient equal to 1 for the diaphragm. Thus, the growth of this organ was isogonic, indicating that it grew at a similar rate to the empty body.

Rumen/reticulum of both males and females showed an allometric growth rate of less than one (negative heterogonic growth) in all genotypes; i.e., the growth rate of this organ was higher than the growth rate of the empty body, most likely because this organ is responsible for breaking down ingested food. Thus, its growth should precede that the body meets the animal's nutritional needs. The F-test for females Santa Inês and Santa Inês x Texel was significant $(\mathrm{F}$-test $=0.0389)$ and males Santa Inês $\mathrm{x}$ Texel and Santa Inês x Bergamasca (F-test $=0.0050)$.

Males from all of the genetic groups showed allometric coefficients equal to 1 for the omasum, indicating that this organ grew at a rate similar to the empty body weight. Abomasums of male and female lamb from the purebred Santa Inês, Texel x Santa Inês and Bergamasca x Santa Inês lamb exhibited negative heterogonic growth; i.e., the abomasum of these animals develops more rapidly than the empty body between 15 and $45 \mathrm{~kg}$. These results may be explained by the role of this organ in absorbing nutrients and meeting the growth demand of the animal.

Coefficients obtained for the small intestine were not consistent or precise, perhaps because this component varied greatly between animals. Male and female large intestines from all of the genetic groups showed coefficients of less than 1 , indicating positive heterogonic growth for this organ, meaning that it grows faster than the empty body.

Mesentery fat in purebred Santa Inês, Texel $\mathrm{x}$ Santa Inês and Bergamasca $\mathrm{x}$ Santa Inês males grew more slowly than the empty body, i.e., presenting an allometric coefficient greater than 1 (positive heterogonic growth), confirming the delayed growth of this fat deposit. However, Ile de France x Santa Inês males and the females from all of the genetic groups showed allometric coefficients equal to one for this component (isogonic growth), indicating that the mesentery/fat grows at a rate similar to the empty body in these lamb.

Males in all of the groups showed coefficients greater than one for perirenal fat, indicating positive heterogonic growth; i.e., this fat deposit grows slower than the empty body. Only females from the Ile de France x Santa Inês group showed the same pattern as the males, while the purebred Santa Inês, Texel x Santa Inês and Bergamasca x Santa Inês groups showed coefficients equal to one (isogonic growth); i.e., the perirenal fat grew at the same rate as the empty body. When comparisons were made between groups, only Texel $\mathrm{x}$ Santa Inês females showed a faster growth rate than the purebred Santa Inês and Bergamasca x Santa Inês groups.

Organs with a high metabolism, including lungs, liver and heart, developed rapidly. KAMALZADEH et al. (1998), previously observed slower growth for the heart, but SANTOS (2002) obtained results similar to those of the present study, with the liver developing faster than the empty body. The F-test was significant to Santa Inês and Santa Inês $x$ Texel (0.0137) and Santa Inês x Texel and Santa Inês x Ile de France (0.0189).

Visceral organs generally appear to have priority over the other body parts regarding the allocation of nutrients. Thus, according to 
KAMALZADEH et al. (1998), they grow faster than the body overall.

Studying the development of the components of the live weight of purebred Santa Inês and Bergamasca x Santa Inês lamb slaughtered at different weights, SANTOS-CRUZ et al. (2009) found that purebred Santa Inês lamb showed relatively early omasum and reticulum/rumen development, while Bergamasca $\mathrm{x}$ Santa Inês lamb exhibited positive heterogonic growth in these organs; i.e., their growth is delayed compared to the empty body. KAMALZADEH et al. (1998) found that the growth of the rumen/reticulum was similar to the live weight of the animal. Comparing the coefficients between the genetic groups, the Texel x Santa Inês male lamb showed a larger coefficient than the Bergamasca $x$ Santa Inês males. This likely occurred because of the greater nutritional requirements of animals from Texel crosses, which caused this organ to grow faster. PIRES et al. (2000) studied the proportions and the growth of several body components of $3 / 4$ Texel $1 / 4$ Ideal lamb relative to the live weight and empty body weight at different slaughter weights, at birth, at weaning (45 days) and at 28 and $33 \mathrm{~kg}$ live weight, and concluded that increasing the live weight at slaughter leads to higher percentages of skin, gastrointestinal tract, intestines and rumen-reticulumomasum-abomasum and lower yields for the carcass. The growth of the rumen-reticulum-omasumabomasum and internal fat is proportionally greater than that of the empty body, which indicates that lamb from Texel x Ideal crosses should be slaughtered at approximately $30 \mathrm{~kg}$ (slaughter weight).

KAMALZADEH et al. (1998) observed earlier growth of the small intestine, due to its high metabolic and protein synthesis activities, and slower growth for the large intestine.

Spleen grew isogonically, meaning that it grew at a rate similar to the empty body. This result was similar to the findings of SANTOS (2002). PEREIRA (2010) studied the allometry of sheep fed with elephant grass silage containing 0, 10, 20 and $30 \%$ dehydrated passion fruit rind and slaughtered at an average weight of approximately $32.4 \mathrm{~kg}$. This investigator reported that inclusion of $30 \%$ dehydrated passion fruit rind in elephant grass silage did not significantly affect the components of the animal's live weight. However, the spleen's growth increased linearly as the percentage of dehydrated passion fruit rind in the silage increased.

All of the lambs, both males and females, exhibited an allometric coefficient equal to one for omental fat, meaning that this fat deposit grew at the same rate as the empty body (isogonic growth). This result differs from what was reported by SANTOS (2002), who detected a slower allometric growth rate in purebred Santa Inês and Bergamasca x Santa Inês lambs. There was no significant difference observed between the genetic groups, indicating that the growth rate of omental fat is independent of the genetic background in the studied groups.

SANTOS (2002) observed slow allometric growth of the mesenteric fat. There were no significant differences in the coefficients between the groups, indicating that the genetic background does not affect the growth of this component.

Allometric coefficients for pelvic fat in males and females from all of the groups, except for Ile de France x Santa Inês females, were greater than one, indicating positive heterogonic growth; i.e., this fat deposit grew slower than the empty body. In contrast, Ile de France x Santa Inês females showed isogonic growth (a coefficient of less than one), indicating that the pelvic fat deposit grew at a rate similar to the empty body. There were no significant differences between males from the various genetic groups, as they grew at similar rates. Among females, however, the coefficient for the Ile de France x Santa Inês group was the lowest, indicating a slower growth rate than purebred Santa Inês, Texel x Santa Inês and Bergamasca x Santa Inês females.

\section{CONCLUSION}

Liver and lungs of both male and female lambs and the kidneys and small intestine of females grew more rapidly than the empty body for all of the genetic groups studied, which were raised in feedlot until they reached a live weight of $45 \mathrm{~kg}$. Diaphragm, bladder and spleen of males and females as well as the omasum in males grew at a rate similar to the empty body.

\section{ETHICS COMMITTEE AND BIOSECURITY}

I declare for all purposes, as the main executor and corresponding author of the research, the project which generated the work: CR-2013-0489- "Allometric growth of non-carcass components in crossed lambs", submitted to Revista Ciencia Rural, was developed before the requirement, and implementation of the Ethics Committee on Animal Research of the Federal University of Lavras. Therefore, there is no certificate for it.

\section{REFERENCES}

AGRICULTURAL RESEARCH COUNCIL (ARC). The nutrient requirement of farm animals. London, 1980. 351p.

BERG, R.T.; BUTTERFIELD, R.M. New concepts of cattle growth. Sidney: Sidney University, 1976. 240p. 
CARVALHO, S. et al. Avaliação da suplementação concentrada em pastagem de Tifton-85 sobre os componentes não carcaça de cordeiros. Ciência Rural, v.35, n.2, p.435-439, 2005. Available from: $<$ http://www.scielo.br/scielo.php?script=sci_ar ttext\&pid=S0103-84782005000200030>. Accessed: Abr. 03, 2013. doi: $10.1590 / \mathrm{S} 0103-84782005000200030$.

FURUSHO-GARCIA, I.F. et al. Componentes de carcaça e composição de alguns cortes de cordeiros Texel $\times$ Bergamácia, Textel $\times$ Santa Inês e Santa Inês puros, terminados em confinamento, com casca de café como parte da dieta. Revista Brasileira de Zootecnia, v.32, n.6, p.1992-1998, 2003. (Supl. 2). Available from: $<$ http://www.scielo.br/scielo.php?script=sci arttext\&pid=S151635982003000800025\&lng=en>. Accessed: Abr. 03, 2013. doi: $10.1590 /$ S1516-35982003000800025.

GRAYBILL, F.A. Theory and application of the linear model. Massachusetts: Duxbury, 1976. 704p.

HAMMOND, J. Principles of animal use. Zaragoza: Acríbia, 1966. 363p.

HUXLEY, J.S. Problems of relative growth. London: Methuen, 1932. 276p.

KAMALZADEH, A. et al. Feed quality restriction and compensatory growth in growing sheep: development of body organs. Small Ruminant Research, v.29, p.71-82, 1998. Available from: $<$ http://www.sciencedirect.com/science/article/pii/ S0921448897001119>. Accessed: Abr. 03, 2013. doi: 10.1016/ S0921-4488(97)00111-9.

KIRTON, A.H. et al. A comparison between 15 ram breeds for export lamb production. 1- Live weights, body components, carcass measurements and compositions. New Zealand Journal Agricultural Research, v.38, p.347-360, 1995.

OLIVEIRA, M.V.V. et al. Desempenho de cordeiros das raças Bergamácia e Santa Inês, terminados em confinamento, recebendo dejetos de suínos como parte da dieta. Revista Brasileira de Zootecnia, v.32, n.6, p.1391-1396, 2003. Available from: <http:/ www.scielo.br/pdf/rbz/v32n6/18428.pdf $>$. Accessed: Nov. 20, 2013. doi: $10.1590 /$ S1516-35982003000600014.

PEREIRA, F.M. Alometria de cordeiros alimentados com silagens de capim elefante com proporções de casca de maracujá desidratada. 2010. 71f. Dissertação (Magister Scientiae) Universidade Estadual do Sudoeste da Bahia, Itapetinga.

PINHEIRO, R.S.B. et al. Rendimento dos nao-componentes da carcaca de cordeiros de diferentes genotipos. Archivos de
Zootecnia, v.57, n.217, p.73, 2008. Available from: $<$ http://www. uco.es/organiza/servicios/publica/az/php/img/web/07_10_13_09N otaRendimentosPinheiro.pdf>. Accessed: Nov. 20, 2013.

PIRES, C.C. et al. Crescimento de cordeiros abatidos com diferentes pesos. 2. Constituintes corporais. Ciência Rural, v.30, n.5, p.869-873, 2000. Available from: <http://www.scielo.br/pdf/ cr/v30n5/a22v30n5.pdf $>$. Accessed: Abr. 03, 2013. doi: 10.1590/ S0103-84782000000500022.

REGAZZI, A.J. Teste para verificar a identidade de modelos de regressão e a igualdade de alguns parâmetros num modelo polinomial ortogonal. Revista Ceres, v.40, n.228, p.176-195, 1993. Available from: <http://www.ceres.ufv.br/CERES/revistas/ V46N266P03499.pdf>. Accessed: Abr. 03, 2013.

REGAZZI, A.J.; LEITE, H.G. Análise de regressão: teoria e aplicações em manejo florestal. Viçosa, MG: Universidade Federal de Viçosa, 1992. 236p. (Textbook).

ROSA, G.T. et al. Proporções e coeficientes de crescimento dos não-componentes da carcaça de cordeiros e cordeiras em diferentes métodos de alimentação. Revista Brasileira de Zootecnia, v.31, n.6, p.2290-2298, 2002. Available from: <http://www.scielo.br/ pdf/rbz/v31n6/a18v31n6.pdf $>$. Accessed: Abr. 03, 2013.

SANTOS, C.L. et al. Estudo do crescimento alométrico dos cortes de carcaça de cordeiros das raças Santa Inês e Bergamácia. Ciência e Agrotecnologia, v.25, n.1, p.149-158, 2001. Available from: < http://www.cloud.editora.ufla.br/revistas/cienagro/pdf/251-2001_17.pdf $>$. Accessed: Abr. 03, 2013.

SANTOS, C.L. Estudo do crescimento e da composição química dos cortes da carcaça de cordeiros Santa Inês e Bergamácia. 2002. 257f. Tese (Doutorado em Zootecnia) - Curso de Pósgraduação em Zootecnia, Universidade Federal de Lavras, MG.

SANTOS-CRUZ, C.L. et al. Desenvolvimento dos componentes do peso vivo de cordeiros Santa Inês e Bergamácia abatidos em diferentes pesos. Revista Brasileira de Zootecnia, v.38, n.5, p.923-932, 2009. Available from: <http://www.scielo.br/pdf/rbz/ v38n5/20.pdf $>$. Accessed: Abr. 03, 2013.

SOUZA JUNIOR, A.A.O. et al. Estudo alométrico dos cortes da carcaça de cordeiros cruzados Dorper com as raças Rabo Largo e Santa Inês. Revista Brasileira de Saúde Producao Animal, v.10, n.2, p.423433, 2009. Available from: <http://www.rbspa.ufba.br/index.php/rbspa/ article/viewFile/1710/823>. Accessed: Abr. 03, 2013.

STATISTICAL ANALYSIS SYSTEM - SAS. User's guide: statistics. Cary, 1999. 956p. 